\title{
ДОСВІД ВПРОВАДЖЕННЯ МІКРОПРОЦЕСОРНОГО УПРАВЛІННЯ РЕГУЛЬОВАНОЮ ЗАСУВКОЮ
}

\author{
Глущенко Григорій Анатолійович \\ Головний конструктор по науковим проектам \\ AТ «ВНДІАЕН» «Науково-дослідний і проєктно-конструкторський інститут \\ атомного та енергетичного насособудування» \\ ORCID 0000-0001-7382-1537 \\ e-mail: gluschenko@vniiaen.sumy.ua
}

Залозний Володимир Васильович завідувач сектору мікропроцесорних систем управління АТ «ВНДІАЕН» «Науково-дослідний і проєктно-конструкторський інститут атомного та енергетичного насособудування» ORCID 0000-0002-7031-8861 e-mail: zalozniy@vniiaen.sumy.ua

Давиденко Андрій Костянтинович, кандидат технічних наук, генеральний директор АТ «ВНДІАЕН» «Науково-дослідний і проєктно-конструкторський інститут атомного та енергетичного насособудування» ORCID 0000-0001-6539-7406 e-mail: davidenko@vniiaen.sumy.ua

В статmі розглянуто особливості впровадження автоматизованої системи керування процесом зняття параметрів модельних проточних елементів горизонтальних відиентрових насосів. Наведено конструктивні особливості електропривода та регулюючої засувки, які ускладнюють процес регулювання. Запропоновано спосіб подолання зони нечутливості, люфта, нелінійності характеристики регулюючого органу. Показано, що високі значення зони нечутливості, люфтта, нелінійності характеристики засувки не є перешкодою для зміни подавання в малих діапазонах середовища, що перекачується. Наведено приклад подолання конструктивно обумовлених недоліків існуючої засувки за допомогою використання алгоритмів керування. Описана алгоритмічна послідовність керування засувкою.

Ключові слова: засувка, електропривод, регулюючий орган, виконавчий механізм, алгоритм регулювання, зона нечутливості, люфт, нелінійність характеристики.

DOI: https://doi.org/10.32845/msnau.2021.1.7

Випробувальний стенд призначений для визначення параметрів модельних проточних частин горизонтальних відцентрових насосів.

Стенд забезпечує можливість проведення випробувань щодо визначення напірної та енергетичної характеристик.

Актуальність проблеми полягає в тому, що наявність перехідних процесів в динамічному режимі зміни подавань середовища, що перекачується [1] потребує детальної поточної фіксації значень контрольованих параметрів під час випробувань для надання можливості наступного більш детального аналізу отриманих даних, а також забезпечення витримання значень необхідного подавання згідно з програмою випробувань. Вирішити ці завдання можливо лише шляхом застосування АСУ для керування засувкою та збиранням та накопиченням отриманих даних.

До застосування автоматизації процес проведення випробувань відбувався вручну.

Основною метою модернізації модельного стенду було створення з урахуванням мікропроцесорного програмно-технічного комплексу автоматизованої системи управління (АСУ), що дозволяє виконувати автоматизоване зняття параметрів модельних проточних елементів горизонтальних

відцентрових насосів.

До складу стенду входять гідравлічне, силове, допоміжне обладнання та вимірювальні прилади. Гідравлічна схема стенда представлена на рис. 1. Експериментальна установка стенду працює по замкнутому контуру і складається 3 експериментального приладу (насоса), баків для води, системи трубопроводів і засувок.

Основним елементом стенду $є$ експериментальний пристрій (насос).

Вимірювання параметрів ступеня, що досліджується, полягало в записі в бланк протоколу випробувань показань приладів на різних подаваннях (витратах). Подавання при цьому регулювалося електрозасувкою дистанційно, за допомогою кнопок на пульті керування на закриття («Менше») або на відкриття («Більше») засувки. Вимірювання параметрів ступеня, що досліджується, рекомендовано проводити від найбільшого подавання до найменшого. Рекомендований інтервал між подаваннями 10-12 м³/год. Після встановлення необхідного подавання витримувалася пауза 2-3 хвилини і тільки після цього в бланк протоколу випробувань записувалися вручну параметри, які контролювалися оператором візуально за показаннями приладів. 


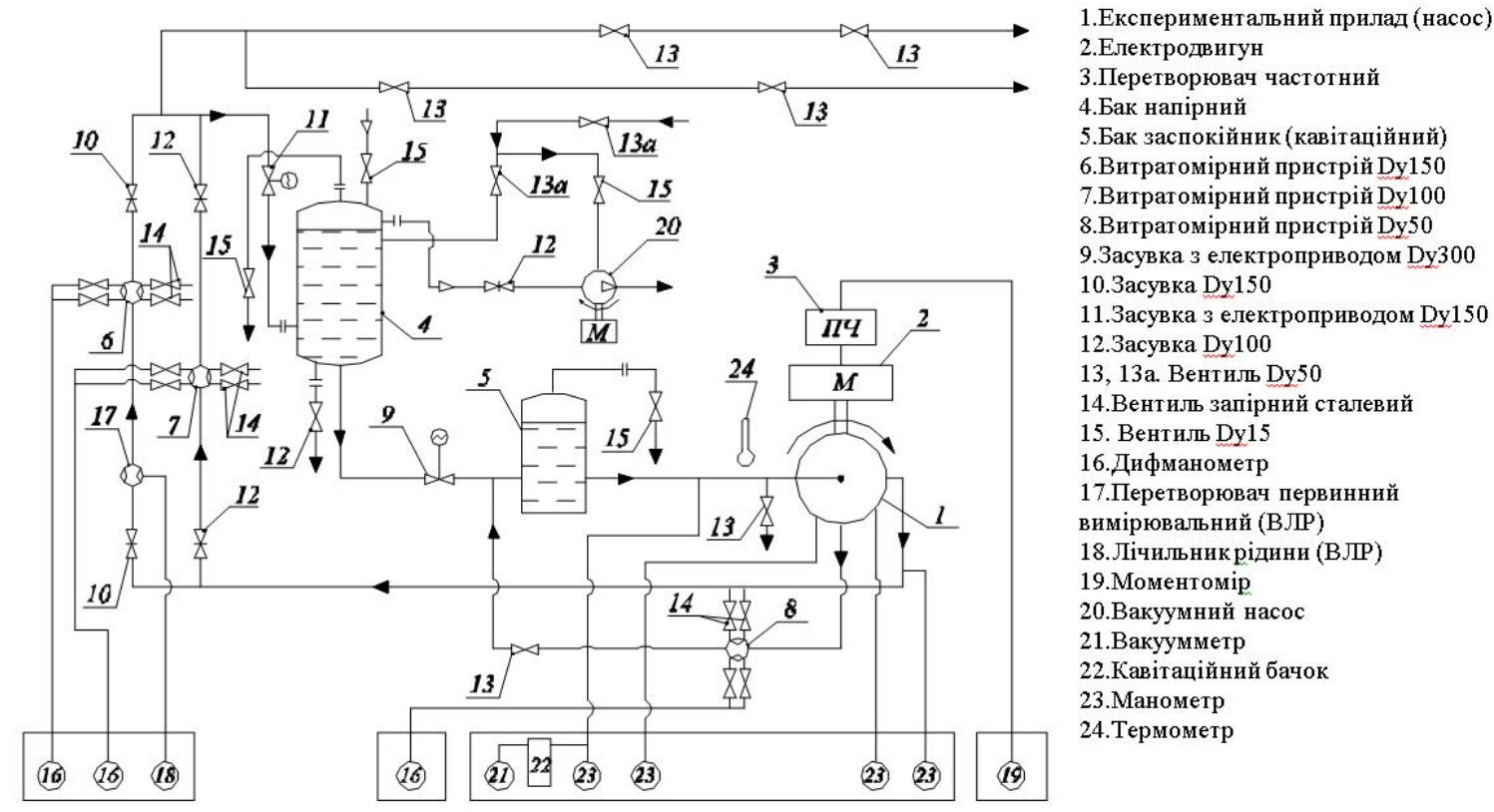

Рис. 1 - Гідравлічна схема стенда

У процесі проведення випробувань у бланк протоколу заносили наступні показання приладів: 2304A);

- значення подавання в м³/год (дисплей приладу ВЛР

- значення тиску на вході та виході з насоса в поділах (манометри);

- значення тиску на вході та виході з проміжного ступеня в поділах (манометри);

- значення витоку через розвантажувальний пристрій у поділах (дифманометр);

- значення моменту в Н·м (дисплей моментоміра);

- значення потужності в кВт (дисплей моментоміра); томіра).

- значення частоти обертання об/хв (дисплей момен-

Після завершення процесу зняття показань дані переносилися з протоколу випробувань до спеціалізованого програмного забезпечення (ПЗ) для подальшої обробки та побудови граффічних характеристик.

Головним регулюючим органом (РО), що забезпечує вимірювання параметрів досліджуваного ступеня, є засувка клинова лита Дн 150, Рн 25 кгс/см² з багатооборотним електроприводом для регулюючої та запірної арматури з блоком управління СЕ.БР-300/34. Електропривод дозволяє виконувати дистанційне та місцеве управління засувкою, у тому числі такі функції:

- переміщення РО у системах автоматичного регулювання технологічними процесами відповідно до командних сигналів, що надходять від зовнішніх керуючих пристроїв. У якості командного сигналу може бути використаний як аналоговий струмовий сигнал в діапазоні 4-20 mA, так і дискретні сигнали на відкриття/закриття засувки;

- переміщення РО з командними сигналами від блоку місцевого управління;

- переміщення РО за допомогою ручного дублера (маховика) на електроприводі;

- сигналізацію досягнення крайніх положень запірного пристрою арматури;
- видачу уніфікованого струмового сигналу положення вихідного валу 4-20 mA;

- місцевий індикатор положення PO на цифровому LED дисплеї (0-100\%).

Налаштування функцій керування, реєстрації даних та інших параметрів виконується пультом дистанційного керування на цифровому дисплеї [2]

Створена АСУ здійснює забезпечення необхідного подавання шляхом керування електрозасувкою, а також фіксування необхідних показань датчиків та перетворювачів.

В результаті проведення випробувань АСУ дозволяє отримати масив усереднених виміряних значень параметрів як таблиці вибірок у файлі формату Excel. В отриманому файлі виконується обчислення розрахункових параметрів, наведених параметрів та побудова графічних діаграм (характеристик напору, потужності та ККД).

АСУ також за результатами роботи надає текстовий файл, що містить посекундні значення десяти попередньо сконфігурованих параметрів системи. Це дає можливість за необхідності провести подальший детальний аналіз поточних значень обраних параметрів протягом усього процесу зняття характеристик.

Застосування АСУ дозволяє:

- формалізувати процес зняття характеристик;

- збільшити точність фіксованих вимірів;

- зменшити час випробувань.

АСУ реалізована на базі промислового контролера (PLC) фірми Siemens SIMATIC 1200 із використанням операторської панелі HMI KTP900 Basic PN. Для вирішення поставленого завдання було придбано перетворювачі тиску вимірювальні AIP - 20/M2-H, виготовлено та змонтовано колонку манометрову. Для отримання значень інших параметрів використовуються наявні датчики та перетворювачі.

АСУ забезпечує керування електрозасувкою в наступних режимах:

1. Дистанційний - оператор може змінювати положення засувки традиційним способом, за допомогою кнопок «Більше», «Менше» на пульті управління. 
2. Ручний - положення засувки у відсотках визначається на операторській панелі.

3. Автоматичний - АСУ переміщує засувку відповідно до алгоритмів програми.

Для виконання поставленого завдання важливо забезпечити точні значення подавання середовища, що перекачується, а це, у свою чергу, можливо тільки при якісному управлінні засувкою.

У процесі налагодження АСУ було виявлено наступні труднощі під час управління положенням існуючої засувки, що визначаються її конструктивними особливостями та механічними властивостями.

1. Мертва зона засувки.

Як зазначалося вище, командні сигнали від зовнішніх керуючих пристроїв (від контролера) можуть бути дискретними або аналоговими.

Мікропроцесорний контролер здатний видати дискретний керуючий імпульс довжиною в десяті частки секунди і менше. Однак це не означає, що такий імпульс буде оброблений електроприводом та призведе до реального мікропереміщення РО. Існує мінімальна тривалість імпульсу, яку може відпрацювати виконавчий механізм (ВМ). Імпульс меншої тривалості видавати в якості керуючого сигналу немає сенсу. Робочу величину мінімальної тривалості імпульсу можна встановити у налаштуваннях імпульсного регулятора. Вона може бути підібрана експериментально. I зазвичай вона встановлюється істотно вище за мінімальну тривалість імпульсу, яку фрізично може «відчути» ВМ. Це робиться через те, що робота електроприводу при інтенсивному режимі регулювання і великій кількості занадто малих керуючих імпульсів супроводжується перегріванням двигуна. Щоб уникнути небезпеки виходу з ладу електропривода, збільшують значення налаштування мінімальної тривалості керуючого імпульсу.

У свою чергу мінімальна тривалість керуючого імпульсу визначає величину мінімального переміщення засувки. Це означає, що є певна межа точності позиціонування ВМ. У процесі виконання керуючого сигналу РО може потрапити в ситуацію, коли мінімальне переміщення «більше» (на відкриття) перевищує задану позицію, а мінімальне переміщення «менше» (на закриття) призводить до занадто низького положення щодо заданого. Процес циклічно повторюється, електропривод нескінченно рухається навколо недосяжної заданої позиції.

Щоб уникнути подібних ситуацій, у налаштуваннях BM, яким у нашому випадку є електропривод, передбачено налаштування параметра Мертва зона (Deadband, Зона нечутливості).

Зона нечутливості, або мертва зона - це величина, що налаштовується. Вона являє собою мінімальну різницю між фактичним положенням засувки (сигналом зворотного зв'язку) і заданим керуючим сигналом, яка призводить до переміщення засувки. Наприклад, заводське налаштування мертвої зони існуючої засувки становить $1,5 \%$. Припустимо, що сигнал зворотного зв'язку показує, що фрактичне положення засувки $50 \%$. Якщо керуючий сигнал буде заданий в діапазоні від 48,5 \% (-1,5\% від фактичного положення засувки) до 51,5 $\%$ (+1,5 \% від фактичного положення засувки), то електропривод засувки не зрушить 3 місця, тому що керуючий сигнал знаходиться в межах мертвої зони. Тільки якщо керуючий си- гнал виходить за межі діапазону мертвої зони, засувка починає реагувати, тобто рухатися, відпрацьовуючи заданий керуючий сигнал.

Цілком доцільно, що налаштування мінімальної тривалості керуючого імпульсу має відповідати мінімальному переміщенню РО, близькому до значення налаштування мертвої зони [3].

Отже, чим менша тривалість мінімального імпульсу і зона нечутливості - тим вища якість управління засувкою та автоматичного регулювання, але тим сильніший знос ВМ та РО та перегрів двигуна електроприводу при інтенсивній роботі регулятора. Чим більша тривалість мінімального імпульсу та зона нечутливості, тим більш грубе регулювання, але менше зношується ВМ і менше перегрівається двигун електроприводу [4].

Для виявлення оптимальних налаштувань ВМ проводилися експериментальні зміни налаштування мертвої зони засувки. Проводилися випробування при заводському значенні налаштування $1,5 \%$, потім 1,0\%, потім налаштування було встановлено 0,8 \%. Візуально на графріку (рис. 2) вихід регулятора відображається плавною лінією, а положення засувки (зворотний зв'язок) - ступінчастою лінією. Висота сходинки визначається налаштуванням мертвої зони засувки.

При встановленні значення налаштування мертвої зони 1,5 \% засувка рухається більш рідкими та більш тривалими імпульсами (вищі сходинки, грубе регулювання). Якість регулювання від цього страждає. На низьких подаваннях один мінімальний імпульс призводить до дуже великої зміни витрати середовища, що перекачується. В таких умовах дуже важко досягти задане значення подавання.

При значенні налаштування мертвої зони 1,0% тривалість імпульсу нижче, точність регулювання дещо вище (сходинки нижче). Але, як і раніше, на низьких витратах один мінімальний імпульс призводить до великої зміни витрати, важко досягти завдання. За горизонтальної форми графіка виходу регулятора засувка зберігає нерухомий стан.

При встановленні значення налаштування мертвої зони 0,8 \% висота сходинок практично не змінилася. Спостереження за засувкою показали, що положення засувки змінюється порціями по 1,4-1,6 \%. Така величина мінімально можливого фізичного переміщення засувки. Виходить, що немає сенсу встановлювати величину мертвої зони менше ніж величина мінімального імпульсу (мінімально можливого переміщення засувки). Це призводить до ефекту пилкоподібних зубців на графіку положення засувки (рис. 2). Причому пилкоподібне переміщення засувки проявляється на ділянках, близьких до горизонтальних. Навіть якщо регулятор переводиться в ручний режим, засувка продовжує з інтервалом 3 сек переміщуватися вгору/вниз, і ніяк не може досягти заданого положення. У цьому випадку потрібно або трохи змінити вихід регулятора (наприклад, на 0,5 \%), щоб полегшити попадання засувки в зону нечутливості, або перейти в дистанційний режим.

Таким чином, занадто мале, занижене настроювальне значення мертвої зони призводить до негативного результату. Якщо привод фізично не може забезпечити таку точність, пилкоподібні переміщення приводу створюють додаткове навантаження на привод. Зазначимо, що фрізично прохідність потоку не змінюється, ці рухи відбуваються у межах люфта. 


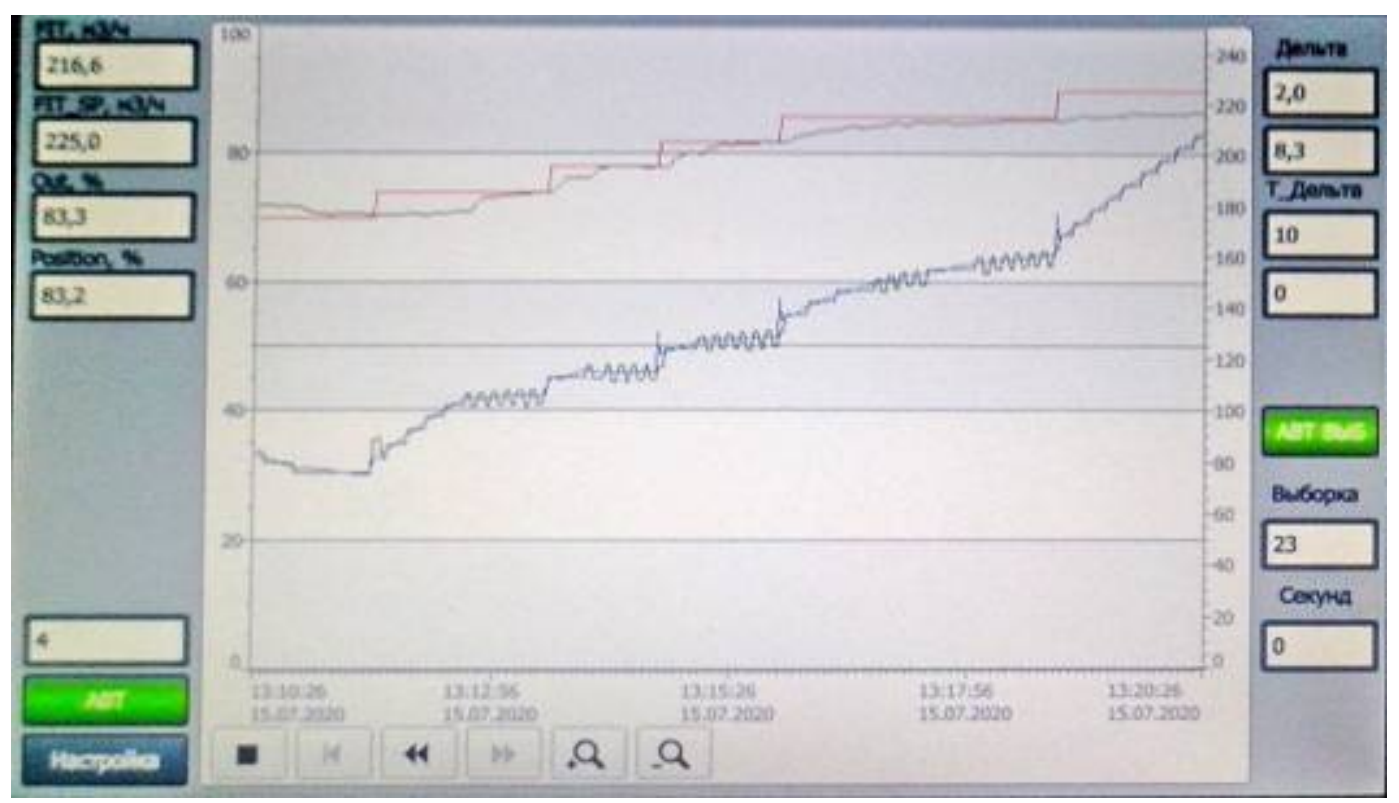

Рис. 2 - Графік положення засувки

3 іншого боку, навіть таке навантаження на привід не $€$ критичним, враховуючи, що тривалість випробування 1,5 години, і після цього виконується відключення стенду та засувки у тому числі. Якість регулювання дещо покращилася при встановленні налаштувань 0,8 \% мертвої зони засувки.

Але після подальших спостережень було прийнято рішення повернутися до заводських налаштувань та встановити налаштування мертвої зони у розмірі 1,5 \%.

2. Люфт засувки.

3 огляду на конструктивні особливості сумарний люфт засувки складається з люфтів всіх з'єднань передавальних частин приводу [5] від валу електродвигуна до диску засувки.

При зміні напрямку руху засувки відбувається процес виробки люфта, під час якого подавання в напірному трубопроводі (і фактичне положення диска засувки) залишається незмінним, а індикатор положення засувки змінюється. Експериментально встановлено, що для нашої засувки сумарне значення люфта становить до $10 \%$ (!) положення засувки. Цей люфт визначає гістерезис на характеристиці засувки (рис. 3). Характеристика засувки отримана на основі множини вимірювань. На характеристиці засувки видно, що графік залежності подавання в напірному трубопроводі (м³/год) від положення засувки (\%) йде різними кривими в залежності від напрямку знімання характеристики - зверху вниз або знизу вгору.

Наявність люфтта призводить до суттєвого уповільнення процесу автоматичного знімання вибірок, тому що при кожному перерегулюванні відбувається зміна напрямку руху засувки та повторна виробка люфта. Також наявність люфрта загалом знижує якість регулювання [6]. Усунути механічний люфт неможливо.

3. Нелінійна характеристика засувки.

Характеристика засувки (залежність подавання від положення засувки) (рис. 3) має значну нелінійність. Щоб змінити подавання в напірному трубопроводі на 10 м³/год від 135 до 125 м³/год, необхідно змінити положення засувки від 100 до 60 \% (тобто практично на третину діапазону). Зміна подавання в напірному трубопроводі від 10 до 0 м³/год відбувається при зміні положення засувки від 1,3 \% до 0 \% (що можна порівняти з переміщенням, що відповідає мінімальному керуючому імпульсу!).

Нелінійність характеристики засувки сильно ускладнює та знижує якість автоматичного регулювання засувкою [7].

Зважаючи на величини мертвої зони, люфтта та нелінійності характеристики засувки, а також за результатами експериментального використання різних режимів системи визнано недоцільним та неефективним використання стандартних алгоритмів автоматичного ПІД-регулювання для управління засувкою.

Оскільки усунути механічні причини вищезгаданих недоліків існуючої засувки неможливо, було прийнято рішення забезпечити необхідні параметри подавання в напірному трубопроводі алгоритмічним шляхом.

Насамперед, забезпечена можливість виконати автоматичне зняття характеристики засувки. Це дозволяє встановити залежність між положенням засувки (\%) та величиною подавання у напірному трубопроводі (м³/год). Для цього достатньо вказати значення для початкового положення засувки, кроку зміни положення та затримки часу перед збереженням величини подавання напірного трубопроводу. Таким чином, можна зробити виміри як у всьому діапазоні з деталізацією положення засувки 2\%, так і на окремо обраній ділянці діапазону з більшою деталізацією. Після натискання кнопки «Старт» АСУ виконає автоматичне вимірювання значень подавання в напірному трубопроводі, послідовно переміщуючи засувку із заданим кроком, починаючи з початкового положення. У кожному положенні, перш ніж зафріксувати значення подавання, витримується пауза відповідно до заданого значення параметра «Затримка». Отримані дані відображаються у таблиці (рис. 4). 


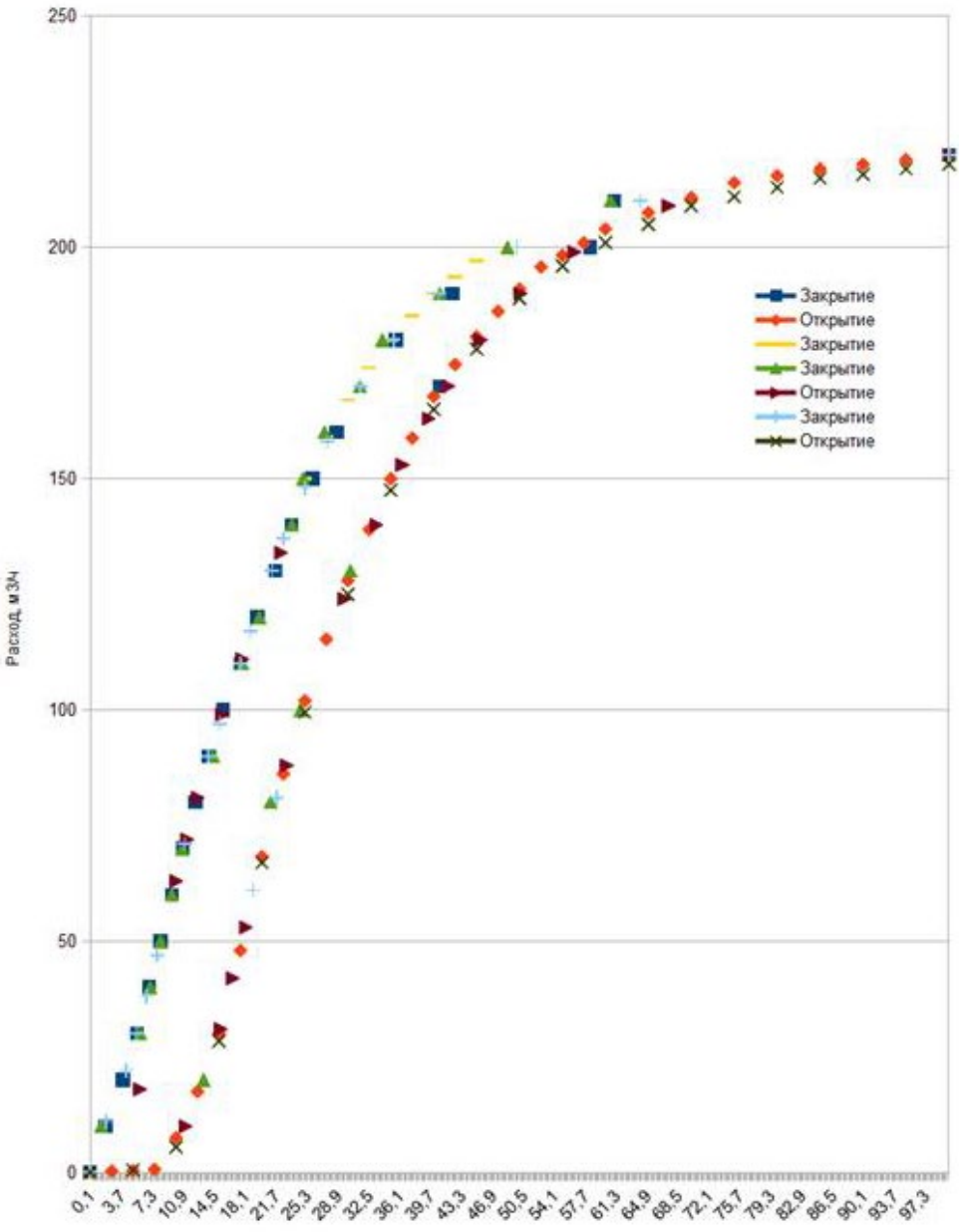

Попожение задвиюси, \%

Рис. 3 - Характеристика задвижки

\begin{tabular}{|c|c|c|c|c|c|c|c|c|c|c|c|c|c|c|}
\hline \multirow{2}{*}{\multicolumn{2}{|c|}{\begin{tabular}{|c|}
$\mathbf{0 , 0 0}$ \\
Положение \\
задвижки
\end{tabular}}} & \multirow{2}{*}{\begin{tabular}{|c|} 
0,0 \\
Подача \\
в нап.тр. \\
FIT \\
м3/4
\end{tabular}} & \multirow{2}{*}{\multicolumn{2}{|c|}{$\begin{array}{c}\text { Положение } \\
\text { задвижки }\end{array}$}} & \multicolumn{5}{|c|}{ с6ор характеристик задвижки } & \multicolumn{2}{|c|}{ дист откл } & \multicolumn{3}{|c|}{ CTAPT } \\
\hline & & & & & $\begin{array}{c}\text { Подача } \\
\text { в нап.тp. } \\
\text { FIT } \\
\text { M3/4 }\end{array}$ & $\begin{array}{r}\text { r } \\
\text { № }\end{array}$ & $\begin{array}{c}\text { оложение } \\
\text { задвижки } \\
\text { Position } \\
\text { \% } \\
\end{array}$ & $\begin{array}{c}\text { Подача } \\
\text { в нап.тp. } \\
\text { FIT } \\
\text { M3/4 }\end{array}$ & & $\begin{array}{c}\text { оложение } \\
\text { Poдвижки } \\
\text { Position } \\
\% \\
\end{array}$ & $\begin{array}{c}\text { Подача } \\
\text { в нап.тp. } \\
\text { FIT } \\
\text { M3/4 }\end{array}$ & № & $\begin{array}{c}\text { оложение } \\
\text { адвижки } \\
\text { Position } \\
\% \\
\end{array}$ & $\begin{array}{c}\text { Подача } \\
\text { в нап.тр. } \\
\text { FIT } \\
\text { M3/4 }\end{array}$ \\
\hline 01 & 100,00 & 0,0 & 11 & 80,00 & 0,0 & 21 & 60,00 & 0,0 & 31 & 40,00 & 0,0 & 41 & 20,00 & 0,0 \\
\hline 02 & 98,00 & 0,0 & 12 & 78,00 & $\mathbf{0 , 0}$ & 22 & 58,00 & 0,0 & 32 & 38,00 & $\mathbf{0 , 0}$ & 42 & 18,00 & 0,0 \\
\hline 03 & 96,00 & 0,0 & 13 & 76,00 & 0,0 & 23 & 56,00 & 0,0 & 33 & 36,00 & 0,0 & 43 & 16,00 & 0,0 \\
\hline 04 & 94,00 & 0,0 & 14 & 74,00 & 0,0 & 24 & 54,00 & 0,0 & 34 & 34,00 & 0,0 & 44 & 14,00 & 0,0 \\
\hline 05 & 92,00 & 0,0 & 15 & 72,00 & 0,0 & 25 & 52,00 & 0,0 & 35 & 32,00 & 0,0 & 45 & 12,00 & 0,0 \\
\hline 06 & 90,00 & 0,0 & 16 & 70,00 & 0,0 & 26 & 50,00 & 0,0 & 36 & 30,00 & 0,0 & 46 & 10,00 & 0,0 \\
\hline 07 & 88,00 & 0,0 & 17 & 68,00 & 0,0 & 27 & 48,00 & 0,0 & 37 & 28,00 & 0,0 & 47 & 8,00 & 0,0 \\
\hline 08 & 86,00 & 0,0 & 18 & 66,00 & 0,0 & 28 & 46,00 & 0,0 & 38 & 26,00 & 0,0 & 48 & 6,00 & 0,0 \\
\hline 09 & 84,00 & 0,0 & 19 & 64,00 & 0,0 & 29 & 44,00 & 0,0 & 39 & 24,00 & 0,0 & 49 & 4,00 & 0,0 \\
\hline 10 & 82,00 & 0,0 & 20 & 62,00 & 0,0 & 30 & 42,00 & 0,0 & 40 & 22,00 & 0,0 & 50 & 2,00 & 0,0 \\
\hline $\begin{array}{l}\text { Исх } \\
\text { nол }\end{array}$ & $\begin{array}{l}\text { кодное } \\
\text { пожение, \% }\end{array}$ & 100, & & 2,0 & $\begin{array}{l}\text { Задержка } \\
\text { с }\end{array}$ & & & акрыт & & & & 51 & 0,00 & 0,0 \\
\hline
\end{tabular}

Рис. 4 - Екран збору характеристик засувки 
Зафіксовані характеристики засувки використовуються у подальшій роботі АСУ наступним чином. У налаштуваннях системи можна задати значення для попередньо встановленої таблиці подавань згідно з програмою майбутніх випробувань. Кожному значенню подавання відповідає певне значення положення засувки, яке можна встановити, використовуючи отримані характеристики засувки. Приклад таблиці відповідності положення засувки та подавання у напірному трубопроводі наведено у табл. 1.

У системі передбачені два параметри, які дозволяють визначити момент початку вибірки - фіксування та збереження показань приладів:

- $\Delta, \mathrm{M}^{3} /$ год - допустиме відхилення $( \pm)$ фактичного значення подавання в напірному трубопроводі від заданого табличного;
- ТА, c - час перебування фактичного подавання в напірному трубопроводі в межах $\Delta$.

Таким чином, з точки зору керування засувкою завдання зводиться до переміщення засувки в таке положення, при якому величина подавання буде знаходитись у межах $\pm \Delta$ від заданої табличної величини подавання протягом заданого часу $T_{\Delta}$.

Для вирішення цього завдання було розроблено оригінальний поступальний регулятор з кроковими коригуючими поправками. Процес автоматичного зняття вибірок йде від максимального подавання до мінімального по сходинкам. Сходинками є встановлені положення засувки (табл. 1). Важливо, щоб табличні значення положення засувки забезпечували фактичне значення подавання в напірному трубопроводі не менше, ніж зазначене в таблиці.

Таблиця 1 - Попередньо визначені положення засувки та значення подавання в напірному трубопроводі для вибірок

\begin{tabular}{|c|c|c||c|c|c|}
\hline № вибірки & Положенння, \% & $\begin{array}{c}\text { Подавання в напірному } \\
\text { трубопроводі, м3/год }\end{array}$ & № вибірки & Положення, \% & $\begin{array}{c}\text { Подавання в напірному } \\
\text { трубопроводі, м3/год }\end{array}$ \\
\hline 1 & 100,0 & 235 & 14 & 15,1 & 105 \\
\hline 2 & 60,0 & 225 & 15 & 13,6 & 95 \\
\hline 3 & 48,0 & 215 & 16 & 12,2 & 85 \\
\hline 4 & 41,0 & 205 & 17 & 10,8 & 75 \\
\hline 5 & 37,0 & 195 & 18 & 9,5 & 55 \\
\hline 6 & 33,0 & 185 & 19 & 8,2 & 45 \\
\hline 7 & 30,0 & 175 & 20 & 6,9 & 35 \\
\hline 8 & 27,2 & 165 & 22 & 5,8 & 25 \\
\hline 9 & 24,7 & 155 & 23 & 2,15 & 15 \\
\hline 10 & 22,7 & 145 & 24 & 1,5 & 5 \\
\hline 11 & 21,0 & 135 & 25 & 0 & 0 \\
\hline 12 & 18,9 & 125 & & & \\
\hline 13 & 16,9 & 115 & & & \\
\hline
\end{tabular}

Процес обслуговування випробувань відбувається наступним чином:

1) При максимально відкритій засувці (положення 100 \%) фріксується поточне значення подавання в напірному трубопроводі.

2) Встановлюється наступне положення засувки згідно з таблицею.

3) Якщо за 30 секунд фактичне значення подавання в напірному трубопроводі не увійшло в межі $\Delta$, формується крокове коригування положення засувки на $0,1 \%$. У разі необхідності п. 3) повторюється циклічно.

4) Якщо фрактичне значення подавання у напірному трубопроводі увійшло в межі $\Delta$, починається відлік секунд перебування фрактичного подавання у напірному трубопроводі в межах $\Delta$.

5) Якщо досягнуто заданий час Т перебування фактичного подавання у напірному трубопроводі в межах $\Delta$, процес зняття вибірки стартує.

6) Якщо після контрольного часу (30 c $\left.+\mathrm{T}_{\Delta}\right)$ процес зняття вибірки не стартував (це означає, що фактичне значення подавання в напірному трубопроводі вийшло за межі $\Delta$ раніше, ніж було досягнуто заданий час $\mathrm{T}_{\Delta}$ ), процес повертається в п. 3), тобто фрормується наступна крокова коригуюча поправка положення засувки.
7) У процесі зняття вибірки засувка залишається нерухомою.

8) Після завершення зняття показань перевіряється умова завершення випробувань. Якщо завершено останню вибірку - роботу закінчено. Якщо це була не остання вибірка - повертаємося у п. 2), тобто номер вибірки збільшується, вибираються табличні значення наступної вибірки і процес повторюється.

Враховуючи вищенаведені величини мертвої зони, люста і нелінійності засувки, виконати крокове коригування положення засувки на 0,1% шляхом простої зміни керуючого сигналу на 0,1 \% неможливо. Оскільки налаштування величини мертвої зони становить $1,5 \%$, таку малу зміну керуючого сигналу взагалі не буде відпрацьовано електроприводом [8]. Тому крокова коригувальна поправка виконується в кілька прийомів.

1. Керуючий сигнал збільшується на 15 \% (напрямок руху засувки змінюється на відкриття).

2. Витримується 5 секунд (пауза, достатня для фізичного виконання переміщення засувки).

3. Потім керуючий сигнал зменшується на 15,1 \% (напрямок руху засувки змінюється на закриття).

Таким чином, сумарно засувка фрактично переміщується на 0,1 \% у бік закриття. Величина $15 \%$, з одного боку, 
дозволяє дійсно виконати переміщення, оскільки ця величина значно більша, ніж налаштування зони нечутливості. 3 іншого боку, величина 15 \% більше, ніж люфрт засувки, і це дозволяє при зміні напрямку руху засувки гарантовано вибрати люфт і коректно переміститися по кривій гістерезиса характеристики засувки.

Подібну процедуру необхідно виконувати також при встановлюванні наступного табличного значення положення при малих подаваннях. 3 табл. 1 видно, що починаючи з вибірки № 15 (13,6 \%) різниця між сходинками положення у наступних вибірках становить менше 1,5 \%. Це означає, що налаштування зони нечутливості перевищує величину зміни керуючого сигналу. Тому встановлення нового значення положення засувки теж потрібно виконувати подібним чином (перехід від вибірки № 15 до вибірки № 16):

1. $13,6 \%+15 \%=28,6 \%$.

2. Витримка 5 секунд.

3. $28,6 \%-16,4 \%=12,2 \%$.
Це дозволить реально переміщувати засувку в діапазонах менших, ніж значення налаштування мертвої зони засувки.

Вищенаведений поступальний регулятор з кроковими коригуючими поправками, добре зарекомендував себе при проведенні випробувань з визначення напірної і енергетичної характеристик на модельному стенді.

\section{Висновки}

У випадках, коли конструктивні особливості РО або ВМ не дозволяють досягти необхідної точності регулювання при використанні стандартних алгоритмів регулювання, одним з можливих шляхів вирішення цієї проблеми є застосування спеціальних алгоритмів.

Високі значення зони нечутливості, люфта, нелінійності характеристик засувки не $є$ перешкодою для зміни подавання в малих діапазонах середовища, що перекачується. За наявності певних умов запірну арматуру можна використовувати в якості регулюючої.

\section{Список використаної літератури.}

1. Кравец А. М. Особенности динамических режимов в гидротранспортных системах с управляемой трубопроводной арматурой / А. М. Кравец., Т. В. Коренькова // Вісник Кременчуцького державного політехнічного університету: Зб. наук. пр. КДПУ. - Вип. 3(44). -Ч. 1. - Кременчук: КДПУ, 2007. - С.162-167

2. Электроприводы многооборотные для регулирующей арматуры с блоком управления СЕ.БР-300/34. РЭ. Союзэнергомаш.

3. Електромеханічні та енергетичні системи, методи моделювання та оптимізації. Збірник наукових праць XI Міжнародної науково-технічної конференції молодих учених і спеціалістів у місті Кременчук 09-11 квітня 2013 р. - Кременчук, КрHУ, 2013. $-386 \mathrm{c}$.

4. Ключев В.И., Терехов В.М. Электропривод и автоматизация общепромышленных механизмов: Учебник для вузов. - М.: Энергия, 1980. - 360 с., ил.

5. Кріль С.О. Дослідження та моделювання комплексу поворотна заслінка - виконавчий механізм на магістральному нафртопроводі // Методи та прилади контролю якості. - Івано-Франківськ. - 2013. - С.84-88.

6. Кравец А. М., Билык А. В., Неборак А. И., Коренькова Т. В. Экспериментальные характеристики гидротранспортной установки при управлении запорно-регулирующей арматурой // Збірник наукових праць XI Міжнародної науковотехнічної конференції молодих учених і спеціалістів «Електромеханічні та енергетичні системи, методи моделювання та оптимізації. ». - Кременчук, КрНУ, 2013. - С.110-111.

7. Борисенко В.Ф., Григорьев С.В., Моргунов В.М. и др. Вопросы повышения производительности нагнетательной станции средствами электропривода. Машиностроение и техносфера XXI века// сб. трудов МНТК в г. Севастополе 13-18 сентября 2004 г., Донецк: ДонНТУ, т.1. - С.73-75

8. Кріль С.О. Застосування цифрових регуляторів у системі автоматичного регулювання тиску на нафртоперекачувальній станції //Вісник інженерної академії України. - Київ,-2015. - №1. - С.219-225.

Hlushchenko H.A., JSC Research and Design Institute for Atomic and Power Pumpbuilding (Ukraine)

Zaloznyi V.V., JSC Research and Design Institute for Atomic and Power Pumpbuilding (Ukraine)

Davydenko A.K., JSC Research and Design Institute for Atomic and Power Pumpbuilding (Ukraine)

Experience of implementation of microprocessor-based control for adjustable gate valve

The article discusses the features of the implementation of an automated control system for the process of recording the parameters of model hydraulic parts of horizontal centrifugal pumps. The design features of the electric actuator and the control gate valve, which complicate the control process, are given. A method to overcome the dead zone, backlash, nonlinearity of the characteristics of the controlling member is proposed. It is shown that high values of the dead zone, backlash, and nonlinearity of the valve characteristics are not an obstacle to change the flow rate of the pumped fluid within small ranges. An example of overcoming the design shortcoming of the gate valve by using control algorithms is given. The algorithmic sequence of gate valve control is described.

Keywords: gate valve, electric actuator, controlling member, actuator, control algorithm, dead zone, backlash, nonlinearity of the characteristic

Дата надходження до редакції: 03.03.2021 